\title{
ELEMEN VEGETASI DALAM PENATAAN RUANG KOTA PADA KORIDOR JALAN JAMIN GINTING BERASTAGI
}

\author{
Nurlisa Ginting', Ahmad Fadil Pohan ${ }^{2}$ \\ ${ }^{1,2}$ Program Studi Magister Teknik Arsitektur Fakultas Teknik Universitas Sumatera Utara \\ Jl. Perpustakaan St. J07 Building, Medan, 20155, Indonesia

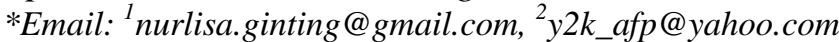

\begin{abstract}
ABSTRAK
Representasi suatu ruang kota dapat diidentifikasi melalui aspek estetika lingkungan. Salah satu unsur utama lingkungan adalah vegetasi. Vegetasi berperan sebagai elemen elastis yang mampu menetralisir kakunya bangunan fisik ruko pada koridor. Keberadaan vegetasi ini perlu ditata dan dikembangkan sehingga mendapatkan estetika visual serta sebagai peneduh atau penetralisir suhu panas pada koridor. Kurang tertatanya vegetasi pada koridor baik dari segi letak maupun dimensi memberi kesan visual negatif dan gersang pada koridor, yang bertolak belakang dengan lokasi koridor yang berada dipegunungan. Penataan vegetasi pada koridor ini meliputi tata letak dan jarak vegetasi, jenis vegetasi, bentuk, ketinggian serta warna dari vegetasi tersebut. Hal ini untuk menciptakan suatu ruang kota yang nyaman, melindungi hak publik dan memiliki konsep. Oleh karena itu tujuan penelitian merumuskan konsep penataan vegetasi sehingga tercipta estetika, karakter, orientasi visual serta menciptakan lingkungan yang asri dan teduh pada koridor. Penelitian ini menggunakan metode deskriptif-kualitatif. Hasil pengamatan dianalisis untuk mendapatkan konsep penataan vegetasi pada koridor Jalan Jamin Ginting Berastagi. Dari hasil penelitian menunjukkan bahwa penataan vegetasi pada ruang terbuka koridor kota mampu menciptakan karakteristik, estetika serta kesan ruang pada jalan. Jenis vegetasi tanaman keras yang disusun disepanjang trotoar memberikan rasa nyaman dan aman dari kendaraan bermotor bagi para pejalan kaki.
\end{abstract}

Kata Kunci: lingkungan, penataan, vegetasi.

\section{PENDAHULUAN}

Lansekap koridor jalan di perkotaan dapat membentuk karakter kota, memberikan kenyamanan dan menjaga kelangsungan hidupnya (Simonds, 1983 dalam Subadyo, 2008). Kehadiran tanaman dalam sebuah lansekap koridor jalan memberikan kepuasan psikologis yang mendalam bagi penghuninya serta menciptakan kenyamanan bagi pengunjung. Perasaan tidak nyaman akan tempat akan mengalihkan keyakinan individu terhadap tempat tersebut dan menimbulkan efek negatif terhadap pariwisata (Ginting, 2016). Kota Berastagi sebagai kota pariwisata akan kehilangan wisatawan apabila keadaan ruang kotanya semakin tidak nyaman, sehingga penataan vegetasi menjadi salah satu faktor penting dalam meningkatkan kenyamanan agar aktivitas pariwisata di Berastagi juga semakin tinggi.
Menurut McCluskey (1992) tanaman memiliki banyak kegunaan dalam kaitannya dengan jalan yaitu, fungsi ekologis (menyerap gas beracun, mengeluarkan oksigen dan memfilter debu), fungsi teknik (mencegah erosi, tameng cahaya, kontrol kebisingan, kontrol iklim, pelindung dari angin dan menjadi elemen pengarah lalu lintas), fungsi arsitektural (memperkaya kualitas visual ruang jalan melaui bentuk, warna, pattern dan tekstur tanaman). Hal ini membuat penataan vegetasi pada ruang jalan sangat penting dilakukan untuk menciptakan kenyamanan dan ketertarikan para pengguna jalan untuk beraktivitas sehari-hari pada ruang jalan maupun dalam perayaan berkala kebudayaan yang telah ditetapkan sebagai sesuatu yang terbuka, ruang masyarakat melakukan aktivitas pribadi dan kelompok. Semakin tinggi aktivitas yang terjadi maka juga akan membuat tingkat ekonomi pada koridor juga tinggi. 
Koridor jalan Jamin Ginting Berastagi merupakan jalur utama kota Berastagi yang dikenal sebagai kawasan pariwisata dengan lokasinya yang berada di pegunungan, tetapi koridor sangat kurang dengan vegetasi atau pepohonan. Koridor pada wilayah penelitian adalah mulai dari Tugu Pahlawan sampai dengan Tugu Kol Berastagi. Vegetasi pada sepanjang koridor ini hanya berada pada pulau jalan dan sebagian berada di trotoar. Vegetasi pada pulau jalan adalah cemara jarum sedangkan pada trotoar adalah mahoni tetai itupun tidak disepanjang koridor (lihat gambar 1). Jenis pohon atau vegetasi ini dianggap kurang efektif karena daunnya yang tidak lebat sehingga tidak dapat menjadi elemen peneduh, terlebih lagi kondisinya yang kurang terawat. Vegetasi pada koridor yang tidak tertata dan terawat belum memberikan visualisasi yang menarik dan sesuai dengan fungsi bangunan komersial dibelakangnya.

Impresi yang baik akan muncul jika seseorang menerima respon positif dari obyek visual yang diamati sehingga obyek visual pada jalur hijau tersebut, seperti vegetasi, perlu memenuhi kaidah penataan estetika visual berdasarkan karakteristik jalan dan kemampuan visual pengamatnya. Pepohonan disepanjang koridor juga dapat menjadi peneduh bagi pejalan kaki di trotoar sekaligus juga sebagai dinding atau buffer antara jalur pedestrian dan jalur kendaraan sehingga para pejalan kaki merasa aman dari kendaraan bermotor. Kurangnya vegetasi pada koridor ini membuat suasana terlihat tandus dan gersang serta tidak merepresentasikan Berastagi sebagai kota wisata yang berada di pegunungan dengan banyaknya pepohonan dan udara segar.

Penelitian ini berupa penataan vegetasi sepanjang koridor. Penataan vegetasi pada koridor ini meliputi tata letak dan jarak vegetasi, jenis vegetasi, bentuk, ketinggian serta warna dari vegetasi tersebut, sehingga tercipta estetika, karakter, orientasi visual serta menciptakan lingkungan yang asri dan teduh pada koridor.

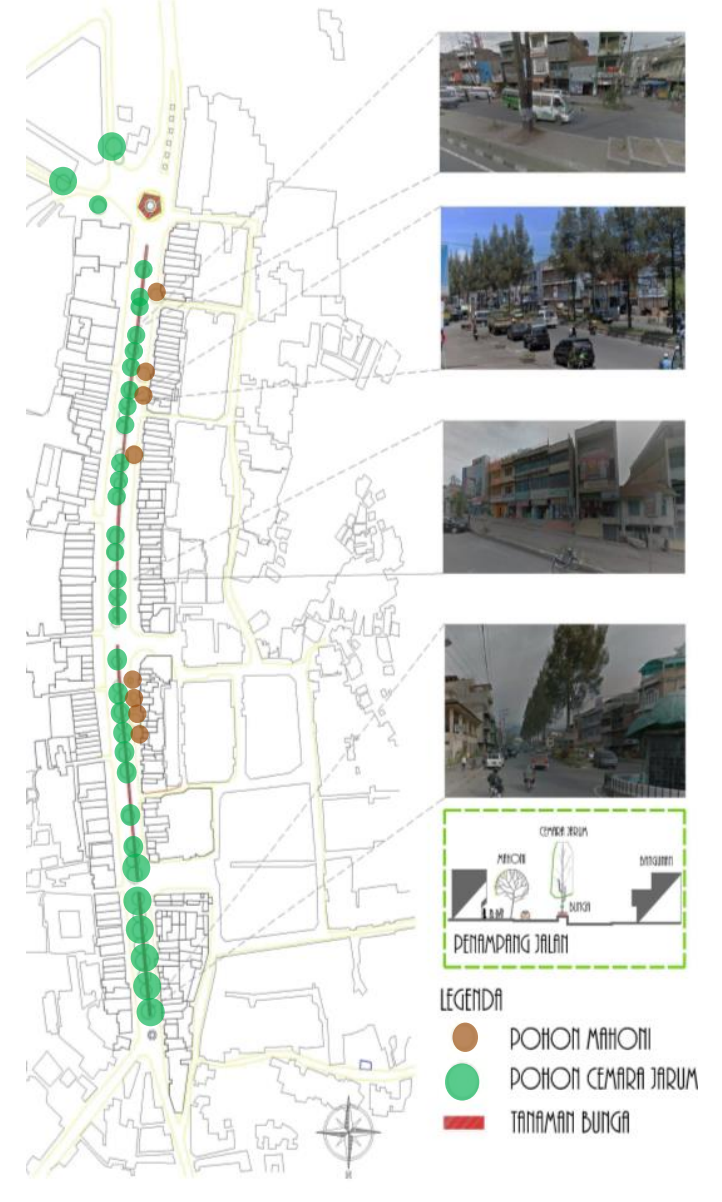

Gambar 1. Keadaan Eksisting Vegetasi pada Koridor 


\section{KAJIAN PUSTAKA}

Tanaman dan bangunan selalu memiliki keterkaitan yang spesial pada koridor karena keduanya memberikan standar dan cara dalam memaknai sebuah lansekap. Fungsi koridor biasanya sebagai jalur sirkulasi yang menghubungkan dua fungsi atau lebih. Bentuk ruang koridor dalam hal ini terdefinisikan oleh bentuk jalan dan elemen bangunan yang ada di kedua sisinya. Dalam perancangan lansekap saat ini, keberadaan tanaman dapat memperkaya nilai arsitektural sebuah bangunan, begitupun sebaliknya bangunan menunjukkan kualitas arsitektural sebuah tanaman (Cullen, 1978). Sejalan dengan pendapat diatas nilai estetis yang dimiliki tanaman, dapat menghadirkan karakteristik sekaligus membentuk suasana arsitektural tertentu (Purwanto, 2008). Sudah seharusnya tata letak dan ketinggian vegetasi dapat mendukung dan memperkaya arsitektural bangunan bukan menutupi bangunan komersial pada koridor. Struktur vegetasi merupakan faktor penting yang mempengaruhi fungsi koridor (Carreiro dkk, 2008). Tata letak vegetasi harus diatur sedemikan rupa tidak terlalu rapat maupun tidak terlalu jarang. Ketinggian vegetasi juga diatur dengan tidak menghalangi visual pada bangunan tetapi masih manaungi ruang jalan dan jalur pejalan kaki sehingga memberikan keteduhan. Tanaman pada koridor jalan dapat dianalogikan sebagai elemen pembentuk dimana tanaman dapat membentuk serial visual ruang (Subadyo, 2008 dalam Bararatin dan Hayati, 2016). Pengulangan obyek dalam lintasan gerak dapat menuntun pergerakan menuju suatu tempat karena kontiniutas visual (Ihar, 1995). Penataan vegetasi yang konsisten dan kontiniu dapat memberikan kontiniutas dan pengarah pada pengguna jalan. Kesinambungan visual dalam pergerakan dengan kesamaan unsur dapat menuntun orang pada suatu klimaks atau tujuan.

Komposisi yang harmonis pada elemen vegetasi diperoleh dari perpaduan antar warna, tekstur dan bentuk tanaman tersebut (Hakim, 2004 dalam Bararatin dan Hayati, 2016). Komposisi vegetasi pada ruang kota bisa dikelola untuk mendukung spesies tertentu yang memiliki prioritas dalam konservasi lingkungan, spesies burung misalnya (Askins dkk, 2012). Komposisi yang harmonis elemen vegetasi sebagai elemen ruang terbuka hijau koridor jalan juga dapat dicapai dengan mengintegrasikan secara visual terhadap unsur lain sehingga dapat berperan menjadi salah satu komponen kota serta menciptakan karakter dan identitas pada ruang jalan kota. Pemakaian vegetasi dengan warna-warna mencolok yang menarik juga dapar menguatkan karakter dan identitas pada koridor tersebut.

Tanda-tanda yang mencolok (landmark) dapat membantu seseorang untuk mengarahkan diri dan mengenal suatu tempat (Lynch, 1992). Komposisi yang harmonis antar tanaman didapatkan jika memenuhi aspek unity, keseimbangan dan irama. Pemilihan jenis tanaman pada koridor jalan dikaitkan dengan kaidah fungsi dan estetika yang dapat membentuk kesan ruang koridor jalan yang diharapkan. Menurut Tredici (2010) vegetasi pada koridor kota salah satunya mempunyai tujuan untuk menciptakan lansekap perkotaan yang estetis dengan prioritas penggunaan tanaman mudah perawatan. Pemilihan vegetasi pada koridor tidak hanya melihat fungsi estetisnya didalam suatu ruang kota tetapi juga harus benar-benar melihat dan mempertimbangkan kaidah fungsionalnya mulai dari bentuknya, ketinggian serta jenis vegetasi itu sendiri.

\section{METODOLOGI PENELITIAN}

Berdasarkan jenisnya penelitian ini
tergolong
kedalam penelitian deskriptif-kualitatif karena dalam prosesnya hasil observasi atau pengamatan berupa penjabaran secara rinci. Pengamatan kualitas visual obyek studi disusun secara deskriptif dengan dipaparkan dan dsisajikan terkait estetika, karakter dan orientasi visual didalam suatu konsep desain penataan. Masalah-masalah yang terjadi pada kondisi eksisting koridor menjadi dasar dari analisa yang dilakukan yang kemudian peneliti melihat referensi yaitu kajian pustaka maupun peraturan yang ada kemudian merumuskan konsep rekomendasi penataan. Konsep rekomendasi untuk desain penataan ini menggunakan metode intuitif yang didasari dari hasil analisa data dan mengembangkan sesuai potensi yang ada pada koridor jalan. Pada rekomendasi untuk desain ini menggunakan metode naratif, dengan penjabaran bagaimana rekomendasi desain yang 
dibutuhkan oleh koridor tersebut sesuai dengan hasil penelitian. Produk gambar dari rekomendasi untuk desain penataan koridor jalan ini berupa sketsa-sketsa manual dan digital site plan, potongan koridor, dan perspektif kawasan

\section{HASIL DAN PEMBAHASAN}

\section{Bentuk}

Bentuk dan ukuran tanaman pada koridor tidak bervariasi. Vegetasi didominasi oleh pohon cemara jarum yang berbentuk columnar yang berada pada median jalan yang tidak bertajuk serta tidak menaungi ruang jalan. Bentuk tanaman yang ada belum menarik secara visual dan pola penataannya juga kurang optimal sehingga tanaman yang ada tidak memiliki kontinuitas secara visual atau terkesan berdiri sendiri. Selain itu belum ada penggunaan bentuk (jenis) tanaman yang khas yang dapat memperkuat karakter koridor jalan namun perlu juga diimbangi dengan menambahkan keragaman bentuk vegetasi untuk menghindari kesan monoton. Tanaman perdu dan bunga dapat dikombinasikan dengan tanaman keras yang berada pada median jalan ataupun jalur pejalan kaki (Gambar 2).

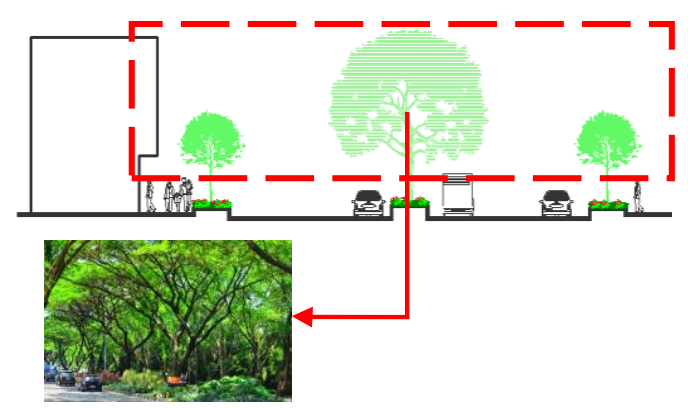

Gambar 2. Tanaman dengan Bentuk Globular

Pada koridor jalan lebih diutamakan penggunaan vegetasi yang berbetuk globular pada median maupun jalur pejalan yang bertajuk serta manaungi jalan sehingga tercipta keteduhan bagi para pengguna jalan. Sejalan dengan hal tersebut menurut Agustin dkk (2014) karakteristik elemen vegetasi pada koridor jalan adalah tipe vegetasi yang dapat menghasilkan bayangan pada median dan bahu jalan sehingga menghasilkan keteduhan bagi pengguna jalan. Pemakaian tanaman berbentuk globular juga memberikan kesan ruang yang akrab dan intim pada koridor. Penggunaan tanaman berbentuk globular memberikan kesan ruang koridor yang lebih tertutup sehingga memberikan peralihan (sekuen) kesan ruang (Bararatin dan Hayati, 2016). Bentuk globular (bulat) pada vegetasi juga memberikan kesan tuntas, dan bergerak atau dinamis (Hakim dan Utomo, 2003).

\section{Warna}

Hasil observasi memperlihatkan minimnya jenis pohon yang memiliki variasi warna pada bunga maupun daun. Selain itu tidak ada variasi warna yang dapat membentuk karakter ruang koridor jalan. Variasi warna daun atau bunga dari vegetasi yang ada belum memberikan visualisasi yang menarik akibat sedikitnya jumlah jenis pohon yang memiliki karakter warna tertentu serta kurang tertata dengan baik. Selain itu tidak adanya pemilihan wana bunga/daun yang tematik (satu jenis warna) berdampak pada belum menguatnya karakter ruang koridor jalan. Hal ini perlu diimbangi dengan adanya variasi warna vegetasi pada koridor misalnya pemakaian bunga-bunga hias khas Berastagi dengan warna yang bervariasi sehingga menciptakan karakter dan identitas pada koridor.

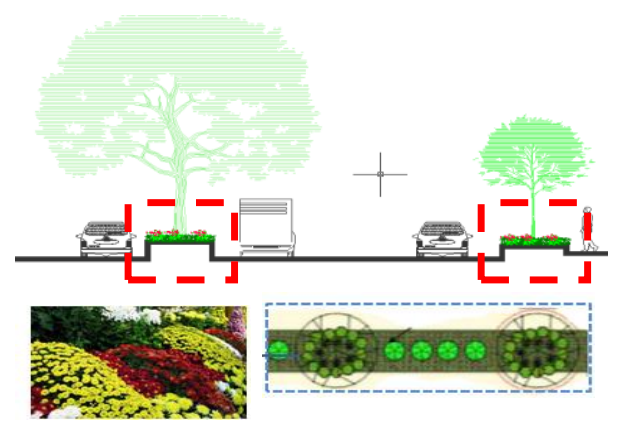

Gambar 3. Tanaman Hias diantara Tanaman Keras

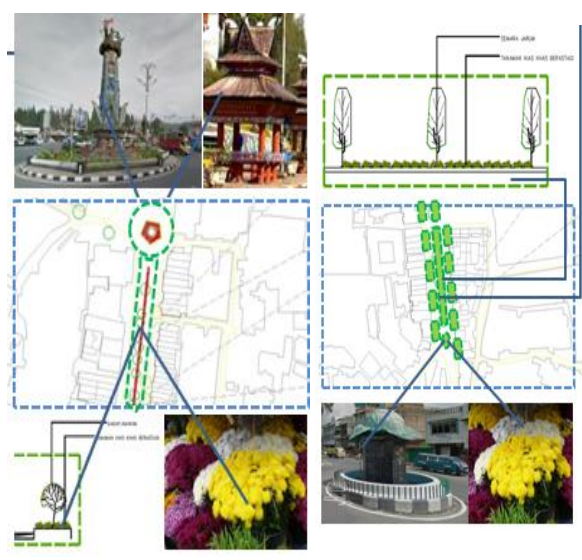

Gambar 4. Tanaman Hias pada Tugu Pahlawan dan Tugu Kol 
Variasi warna daun atau bunga dari vegetasi yang ada menciptakan karakter dan pengalaman visual yang menarik pada saat melintasi koridor. Jenis dan jumlah pohon dengan karakter warna tertentu juga harus dipertimbangkan. Kualitas visual suatu lansekap pada ruang kota dapat dihasilkan salah satunya dengan kombinasi warna (Daniel, 2001). Vegetasi pada lansekap koridor jalan juga menghasilkan suasana alami di lingkungan perkotaan dengan berbagai tekstur dan warna (Subadyo, 2008).

Penggunaan bunga lokal dengan warnawarna menarik diterapkan pada sekeliling Tugu Kol dan Tugu Pahlawan sebagai ikon kota yang dapat memperkaya pengalaman visual yang dapat memberi tautan pada memori koridor itu sendiri. Warna-warni yang dihasilkan oleh tanaman hias dan tanaman keras tidak hanya mempengaruhi kenyamanan manusia melainkan juga mempengaruhi suasana dan kesan khas dari suatu ruang (Frick dan Suskiyatno, 2007). Tanaman hias khas lokal ini yang dikombinasikan antara tanaman keras pada median jalan dan jalur hijau pedestrian akan memberikan kesan visual yang kuat pada koridor (Gambar 3 dan 4).

\section{Jenis Vegetasi}

Jenis vegetasi pada koridor tidak variatif dan kurang terawat. Jenis vegetasi pada jalan hanya pohon cemara jarum dan pohon mahoni, sedangkan pada trotoar tanaman bunga pada pot itupun dengan kondisi yang tidak terawat dan mati. Sangat perlu adanya keragaman jenis vegetasi yang dapat menaungi pemakai jalan serta pejalan kaki serta menciptakan karakter dan variasi pandangan pada koridor.

Penggunaan jenis vegetasi yang beragam seperti tanaman keras, perdu, semak dan groundcover pada jalur hijau jalan yang disusun secara mengelompok atau memanjang dengan tanaman keras (pohon besar) sebagai unsur dominan (focal point) dan tanaman lain (perdu, semak, ground coversebagai unsur pendukung). Variasi jenis vegetasi pada ruang koridor jalan merupakan jalur hijau perkotaan yang berbentuk linier yang secara fungsional dan visual memberi sumbangan dalam pengoptimalan keseimbangan ekologi dan keanekaragaman hayati (Subadyo, 2008). Jenis vegetasi yang diterapkan tidak hanya memikirkan fungsi estetisnya terhadap koridor tetapi juga harus mempertimbangkan kaidah fungsionalnya.
Tanaman keras dengan batang pohon yang keras dan kuat seperti pohon kayu manis, pohon trengguli, pohon akasia dan pohon mahoni pada median jalan digunakan sebagai faktor keamanan, sehingga batang pohonnya yang keras dapat meminimalisirkan dampak dari kecelakaan lalu lintas yang terjadi di jalan. Pohon trengguli dengan warna bunga yang berwarna kuning membuat ruang jalan pada koridor semakin menarik.

Pada jalur pejalan kaki lebih dipilih jenis vegetasi dengan dengan ukuran pohon yang lebih kecil daripada pohon pada median jalan.

Hal ini memungkinkan fasade bangunan tidak tertutupi dan dapat dinikmati pengguna jalan. Pemilihan vegetasi juga berbentuk globular sehingga tetap dapat menaungi jalur pejalan kaki sehingga membuat jalur pedestrian terasa teduh.

Pada jalur pejalan kaki dipilih jenis vegetasi yaitu pohon bunga kupu-kupu, pohon bungur dan pohon tanjung (Gambar 5). Pemilihan vegetasi pada median jalan dan jalur pejalan kaki melihat Peraturan Menteri Pekerjaan Umum Tahun 2008 Nomor 05/PRT/M/2008 dengan mempertimbangkan jenis vegetasi dengan akar yang tidak merusak konstruksi jalan dan jalur pedestrian, tanggap terhadap iklim setempat, mudah perawatan dan jumlahnya yang banyak. Aspek irama dan keharmonisan vegetasi didapatkan melalui penambahan unsur pendukung dari obyek yang dominan, tanaman yang memiliki ukuran yang lebih kecil seperti tanaman perdu, semak dan groundcover atau diperlukan tanaman yang memiliki urutaan warna kontras, sedang dan lembut. Penggunaan variasi jenis tanaman dapat menimbulkan harmonisasi visual koridor jalan dan mencegah kemonotonan. Kemonotonan lansekap koridor jalan juga dapat menimbulkan hipnosis perjalanan, sehingga bisa menimbulkan kecelakaan (Noor, 1997 dalam Subadyo, 2008). Variasi jenis vegetasi juga dapat memperkuat interaksi antar spesies sehingga menghasilkan ekosistem yang kuat pada ruang kota (Askins dkk, 2012 dan Tredici 2010). 


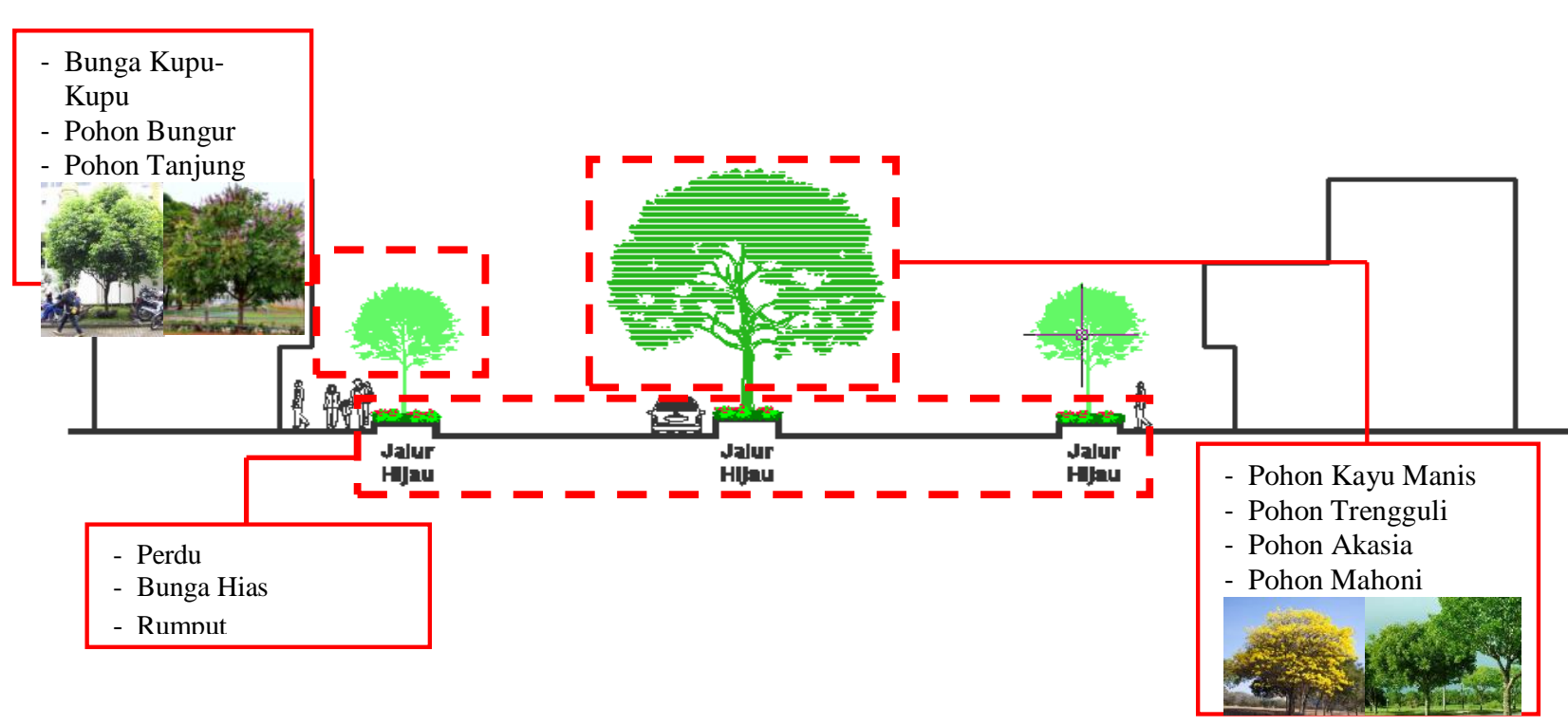

Gambar 5. Jenis Vegetasi Pada Jalur Hijau

Hal ini memungkinkan fasade bangunan tidak tertutupi dan dapat dinikmati pengguna jalan. Pemilihan vegetasi juga berbentuk globular sehingga tetap dapat menaungi jalur pejalan kaki sehingga membuat jalur pedestrian terasa teduh.

Pada jalur pejalan kaki dipilih jenis vegetasi yaitu pohon bunga kupu-kupu, pohon bungur dan pohon tanjung (Gambar 5). Pemilihan vegetasi pada median jalan dan jalur pejalan kaki melihat Peraturan Menteri Pekerjaan Umum Tahun 2008 Nomor 05/PRT/M/2008 dengan mempertimbangkan jenis vegetasi dengan akar yang tidak merusak konstruksi jalan dan jalur pedestrian, tanggap terhadap iklim setempat, mudah perawatan dan jumlahnya yang banyak. Aspek irama dan keharmonisan vegetasi didapatkan melalui penambahan unsur pendukung dari obyek yang dominan, tanaman yang memiliki ukuran yang lebih kecil seperti tanaman perdu, semak dan groundcover atau diperlukan tanaman yang memiliki urutaan warna kontras, sedang dan lembut. Penggunaan variasi jenis tanaman dapat menimbulkan harmonisasi visual koridor jalan dan mencegah kemonotonan. Kemonotonan lansekap koridor jalan juga dapat menimbulkan hipnosis perjalanan, sehingga bisa menimbulkan kecelakaan (Noor, 1997 dalam Subadyo, 2008). Variasi jenis vegetasi juga dapat memperkuat interaksi antar spesies sehingga menghasilkan ekosistem yang kuat pada ruang kota (Askins dkk, 2012 dan Tredici 2010).

\section{Tata Letak dan Jarak Vegetasi}

Hasil observasi terhadap aspek penempatan vegetasi menunjukkan tidak adanya penataan atau penempatan vegetasi yang terencana baik, baik dari aspek jarak tanamnya. Selain itu tanaman yang tertata hanya di beberapa penggal jalan saja selanjutnya mengalami diskontinuitas sedangkan pada jalur pejalan kaki belum terdapat jalur hijau sebagai pemisah antara pejalan kaki dengan kendaraan bermotor. Pada muka bangunan komersil keberadaan tanaman sangat minim karena dianggap dapat mengganggu pandangan konsumen.

Secara umum tidak nampak adanya penataan atau penempatan pohon-pohon atau tanaman secara terencana yang membentuk pola tatanan yang kontinyu serta harmonis. Diperlukan penataan secara terencana atau membentuk pola irama yang dinamis sehingga lebih menarik. Dengan banyaknya bangunan perdagangan atau pertokoan, keberadaan vegetasi kerap dianggap sebagai pengganggu sehingga titik-titik tanam menjadi berkurang. Oleh karena itu dengan menyediakan jalur hijau yang jelas diharapkan bangunan-bangunan tersebut dapat melakukan penyesuaian.

Keragaman jenis tanaman harus diimbangi dengan penataan yang mempertimbangkan komposisi estetika visual seperti perhatian pada aspek irama, keseimbangan dan unity sehingga memberikan pengalaman visual yang menarik pada saat melintasi koridor jalan kota. Wujud dan 
komponen variasi vegetasi yang ditempatkan secara konsisten akan menggerakkan perhatian mata sehingga menimbulkan irama (ritme). Irama akan menciptakan harmoni, mengatur aksentuasi dan mengikat bagian ruang menjadi satu kesatuan (Hakim dan Utomo, 2003).

Konsep penataan jarak tanam pohon pada jalur pedestrian 15-20 meter agar vegetasi tidak menghalangi pandangan ke bangunan. Jarak dan tanaman pada muka bangunan perdagangan yang lebar dimaksudkan agar tidak menghalangi pandangan ke bangunan atau obyek komersil (Bararatin dan Hayati, 2016). Jalur hijau pada jalur pedestrian bersifat komunal dengan panjang 3 meter dan lebar 1 meter dengan tetap menyediakan akses dari jalan ke jalur pedestrian (Gambar 6).

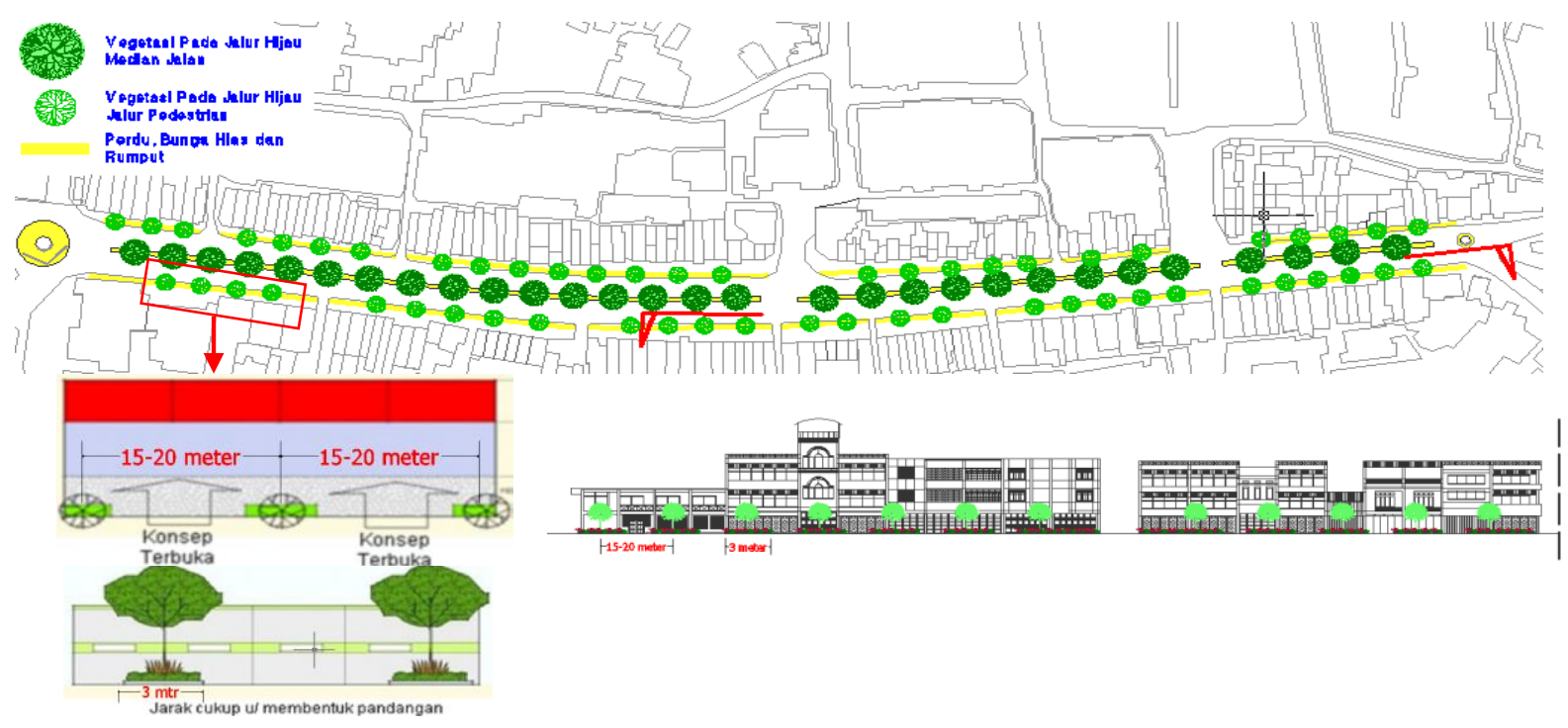

Gambar 6. Tata Letak dan Jarak Vegetasi

Pada median jalan jarak tanam lebih rapat yatu 10 meter. Menurut Durham Region Arterial Corridor Guidelines (2007) penanaman pohon pada median jalan dengan jarak 8-10 meter untuk memberikan arah secara terus menerus di koridor, juga memastikan penempatan pohon tidak menghalangi pandangan pengemudi di persimpangan dan jalan masuk. Peletakan vegetasi juga tidak melupakan jarak pandang pengemudi pada daerah persimpangan jalan. Pada mulut persimpangan diperlukan daerah terbuka agar tidak menghalangi pandangan pemakai jalan (Gambar 7).

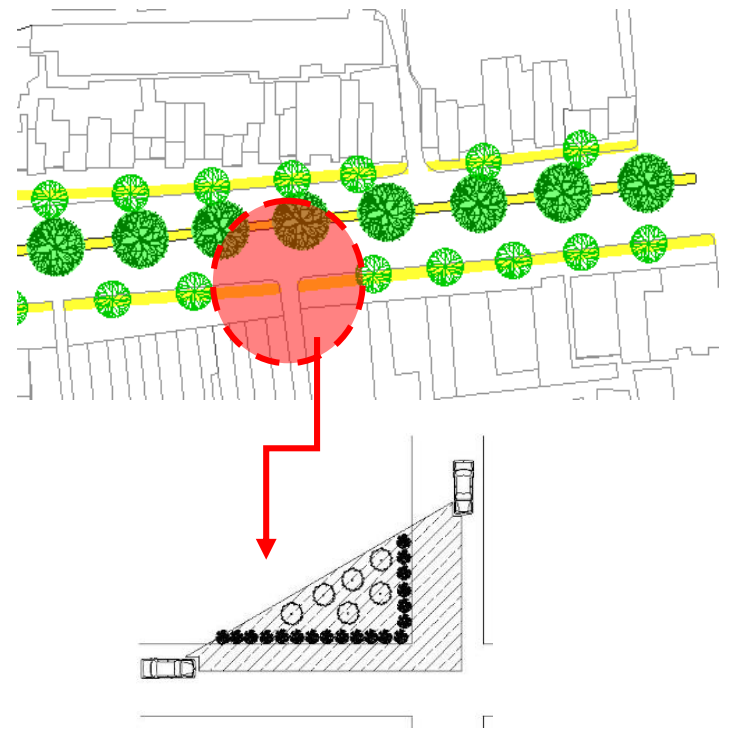

Gambar 7. Peletakan Vegetasi pada Persimpanga 


\section{Ketinggian Vegetasi}

Vegetasi pada koridor mempunyai ketinggian yang tidak teratur serta mengganggu visual serta utilitas yang ada. Pengaturan ketinggian vegetasi vegetasi dimaksudkan agar penanaman vegetasi pada median jalan maupun jalur hijau pejalan kaki tidak menimbulkan gangguan terhadap jaringan utilitas (telepon dan listrik), tidak menghalangi pandangan terhadap bangunan serta tidak menghalangi udara dan sinar matahari ke bangunan komersial yang ada dibelakangnya.

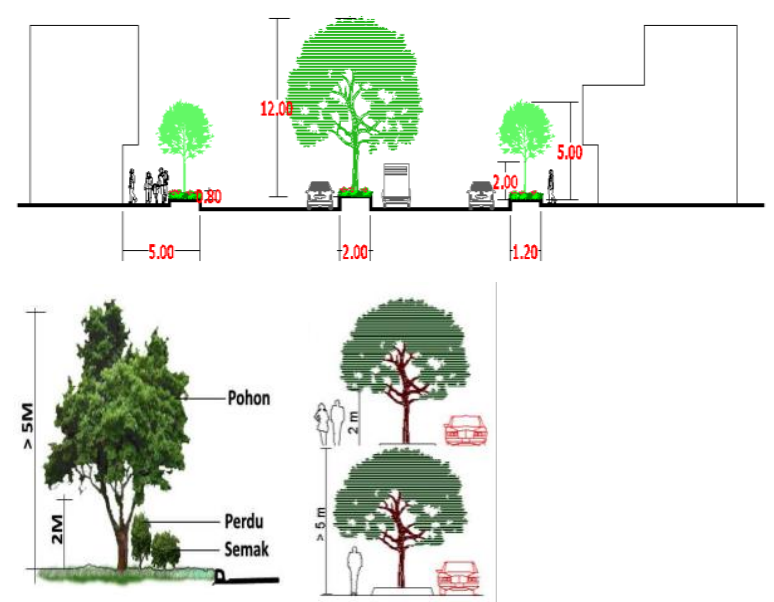

Gambar 8. Ketinggian Vegetasi

Ketinggian tanaman keras pada jalur pejalan kaki maksimal 5 meter dengan jarak cabang pohon dari tanah 2 meter. Hal ini memungkinkan agar cabang pada batang pohon tidak menggangu pejalan kaki dan pandangan pengendara pada persimpangan. Sedangkan ketinggian pohon pada median jalan adalah lebih dari 5 meter dengan tinggi maksimal 12 meter. Tinggi pohon pada median jalan dimaksudkan untuk menghalangi sinar matahari yang sangat terik atau terang khususnya pada siang hari, sedangkan tanaman yang lebih rendah pada jalur pejalan kaki di muka bangunan berfungsi untuk meredam refleksi dari material kaca yang banyak digunakan atau diadopsi oleh bangunan komersial di belakangnya (Hakim dan Utomo, 2003).

Ketinggian perdu dan tanaman hias maksimal $80 \mathrm{~cm}$ (Gambar 8). Ketinggian perdu dan bunga hias dengan batas maksimal dibawah pinggang memberikan kesan ruang yang sangat kuat sebagai fungsi pengarah dan pembentuk pola sirkulasi. Tanaman hias dan perdu dengan ketinggian yang rendah juga memberikan proporsi yang cukup antara tanaman, lingkungan sekitarnya serta manusia.

\section{KESIMPULAN}

Arahan konsep desain adalah melakukan peletakan pohon pada median jalan 10 meter sedangkan pada jalur pedestrian $15-20$ meter dengan ketinggian maksimal 5 meter agar vegetasi tidak menghalangi pandangan ke bangunan. Jalur hijau pada jalur pedestrian bersifat komunal dengan panjang 3 meter dan lebar 1 meter dengan tetap menyediakan akses dari jalan ke jalur pedestrian. Orientasi visual pada koridor dihasilkan dengan adanya kesinambungan visual yang dicapai melalui peletakan vegetasi (jalur hijau) yang menerus tanpa terputus lintasannya di sepanjang koridor jalan. Deretan peletakan pohon disepanjang jalan juga menjadi pengarah kepada pengguna jalan.

Penggunaan jenis vegetasi yang beragam seperti tanaman keras, perdu, semak dan groundcover pada jalur hijau jalan yang disusun secara mengelompok atau memanjang dengan tanaman keras (pohon besar) sebagai unsur dominan (focal point) dan tanaman lain (perdu, semak, groundcover) sebagai unsur pendukung pada jalur hijau yang disusun dengan komposisi yang saling mendukung menghadirkan ruang pejalan kaki dan jalan yang memadai secara teknis dan visual. Komposisi visual yang estetis (unity, keseimbangan, irama) yang dicapai melalui penggunaan warna-warna pada vegetasi, bentuk, ukuran dan jenis vegetasi yang disusun dan diletakkan secara harmonis dan proporsional pada ruang terbuka di koridor. Bentuk globular dengan tajuk daunnya yang menaungi jalan memberi kesan ruang yang intim. Ukuran dan tinggi vegetasi pada jalur pejalan kaki adalah maksimal 5 meter dengan jarak cabang 2 meter dari tanah sehingga tidak menghalangi pejalan kaki dan pandangan pengendara, 5-12 meter ketinggian pohon pada median jalan serta $80 \mathrm{~cm}$ untuk ketinggian perdu dan bunga hias.

Pemilihan jenis vegetasi khususnya tanaman keras juga harus memperhatikan aspek fungsionalnya, akarnya yang tidak merusak konstruksi jalan ataupun jalur pejalan kaki serta ramah perawatan. Jenis vegetasi yang diarahkan adalah pohon kayu manis, pohon trengguli, pohon akasia dan pohon mahoni pada median jalan. Sedangkan pohon bunga kupu-kupu, 
pohon tanjung dan pohon bungur pada jalur hijau di sepanjang jalur pedestrian.

Penggunaan tanaman lokal seperti bungabunga hias berwarna warni yang diterapkan pada median jalan dan jalur hijau pejalan kaki menguatkan karakter dan identitas koridor jalan. Penerapan tanaman lokal juga merupakan salah satu upaya dalam pelestarian lingkungan pada kawasan. Pemakaian bunga hias khas lokal pada Tugu Pahlawan dan Tugu Kol pada koridor juga menguatkan obyek landmark tersebut sebagai orientasi pergerakan.

Diperlukan pengkajian yang mengarah kepada pengaruh rasio vegetasi terhadap komposisi energi perkotaan, tata cara mengurangi perubahan kondisi klimatologi dan kondisi fisik visual perkotaan dengan mengkaitkannya pada vegetasi koridor jalan. Mencari kemungkinan pengembangan lansekap koridor jalan yang dapat menghubungkan ruang ruang hijau perkotaan secara menerus sambung menyambung sehingga membentuk struktur ruang hijau yang mantap dan seimbang sehingga dapat meningkatkan kenyamanan pada koridor ruang kota, estetika dan keamanan serta menciptakan keseimbangan lingkungan yang membuat terciptanya suatu kota ekologis.

\section{Daftar Pustaka}

Agustin, Etty, Santosa, Happy Ratna dan Soemardiono, Bambang, (2014) The Application Of Sustainable Urban Street Concept In A.Yani Surabaya Street Corridor Arrangement To Improve The Quality Of Corridor Environment. International Journal of Education and Research, 2 (2), 1-16.

Askins, Robert. A, Folsom-O'Keefe, Corrine. M dan Hardy, Margaret. C, (2012) Effects of Vegetation, Corridor Width and Regional Land Use on Early Successional Birds on Powerline Corridors. PLoS One Journal, 7 (2), 1-10.

Bararatin, Kirami dan Hayati, Arina, (2016) Penataan Jalur Hijau di Surabaya Berdasarkan Karakteristik Jalan dan Kemampuan Visual Pengamat, Studi Kasus: Jalan Mastrip Surabaya. EMARA Indonesian Journal Of Architecture, 2 (1), 1-12.
Carreiro, Margaret. M, Song, Yong-Chang dan Wu, Jianguo, (2008) Urban Forestry and the Eco-City: Today and Tomorrow. New York: Springer.

Cullen, Gordon (1978) Townscape. London: The Architectural Press.

Durham Region Arterial Corridor Guidelines, 2007.

Frick, Heinz dan Suskiyatno, FX. Bambang, (2007) Dasar-dasar Arsitektur Ekologis, Konsep Pembangunan Berkelanjutan dan Ramah Lingkungan. Yogyakarta: Kanisius.

Frick, Heinz dan Mulyani, Tri Hesti, (2006) Arsitektur Ekologis. Yogyakarta: Kanisius.

Ginting, Nurlisa, (2016) How Self-Efficacy Enhance Heritage Tourism in Medan Historical Corridor, Indonesia. ProcediaSocial and Behavioral Sciences, 234, 193-200.

Hakim, Rustam dan Utomo, Hardi (2003) Komponen Perancangan Arsitektur Lansekap, Prinsip-Unsur dan Aplikasi Desain. Jakarta: Bumi Aksara.

Ihar, HK, (1995) Pedoman untuk Merancang Bangunan. Jakarta: Gramedia.

Lynch, Kevin (1992) The Image Of The City. London: The MIT Press.

McCluskey, Jim (1992) Roadform \& Townscape. London: Library of Congress Cataloguing.

Peraturan Menteri Pekerjaan Umum Tahun 2008 Nomor 05/PRT/M/2008 tentang Pedoman Penyediaan dan Pemanfaatan Ruang Terbuka Hijau di Kawasan Perkotaan.

Purwanto, Edi (2008) Eksistensi Ruang Terbuka Hijau dalam Mewujudkan Eco Urban. Prosiding Seminar Nasional Eco Urban Design, Potensi Dan Tantangan Perencanaan Kota-Kota Indonesia Di Masa Mendatang. Universitas Diponegoro, Semarang. 
Subadyo, A. Tutut (2008) Pemanfaatan Lansekap Koridor Jalan Untuk Perancangan Kota Ekologis. Prosiding Seminar Nasional Eco Urban Design, Potensi dan Tantangan Perencanaan Kota-Kota Indonesia Di Masa Mendatang. Universitas Diponegoro, Semarang.

Tredici, Peter Del (2010) Spontaneous Urban Vegetation: Reflections of Change in a Globalized World. Berghahn Journal, 5 (3), 299-315. 